\title{
HUBUNGAN ANTARA POLA ASUH DEMOKRATIS TERHADAP KONSEP DIRI REMAJA DI SMAN 11 KENDARI
}

\section{RELATIONSHIP BETWEEN DEMOCRATIC PARENTING PATTERNS TO ADOLESCENT SELF-CONCEPT IN SMAN 11 KENDARI}

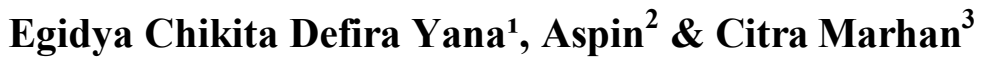 \\ Program Studi Psikologi \\ Fakultas Keguruan dan Ilmu Pendidikan, Universitas Halu Oleo \\ egidvavana@gmail.com ${ }^{1}$, aspin.psi@gmail.com ${ }^{2}$, chetmarhan02@gmail.com ${ }^{3}$
}

\begin{abstract}
ABSTRAK : Pola asuh demokratis adalah suatu bentuk pola asuh yang memperhatikan dan menghargai kebebasan anak, adanya komunikasi yang dialogis antara anak dan orang tua, dan adanya sikap hangat yang ditunjukkan oleh orang tua kepada anaknya. Pola asuh orang tua memiliki peranan penting dalam upaya pembentukan konsep diri, pembentukan konsep diri remaja tidak terlepas dari penerapan pola asuh demokratis, yang menerapkan komunikasi dua arah, sehingga pembentukan konsep diri akan tercipta dari interaksi antara orang tua dengan anaknya. Penelitian ini bertujuan untuk mengetahui apakah ada hubungan antara pola asuh demokratis terhadap konsep diri remaja di SMAN 11 Kendari. Penelitian ini menggunakan metode kuantitatif dengan desain korelasional. Sampel dalam penelitian ini berjumlah 117 siswa. Teknik sampling yang digunakan adalah purposive sampling. Sumber data penelitian ini adalah siswa diukur dengan menggunakan skala pola asuh demokratis dan skala konsep diri. Analisis data menggunakan teknik korelasi Pearson Product Moment. Hasil dari penelitian ini menunjukan nilai koefisien korelasi $(r)=0,117$ dengan nilai signifikansi $(\mathrm{p})=0.104$. Nilai tersebut lebih besar dari 0.05 , sehingga dapat diartikan bahwa tidak ada hubungan antara pola asuh demokratis terhadap konsep diri remaja di SMAN 11 Kendari.
\end{abstract}

Kata Kunci: Pola Asuh Demokratis, Konsep Diri, Remaja

ABSTRACT: Democratic parenting is a form of parenting that pays attention to and respects children's freedom, dialogic communication between children and parents, and the warm attitude that shown by parents to their children. Parenting style has an important role in the formation of children self-concept, the formation of adolescent self-concept can not be separated from the application of democratic parenting, which applies two-way communication, so that the formation of self-concept will be created from the interaction between parents and their children. This research aimed to determine whether there is a relationship between democratic parentingon adolescent self-concept at SMAN 11 Kendari. This research uses quantitative methods with correlational designs. The sample in this study amounted to 117 students. The sampling technique used was purposive sampling. The data source of this study were students measured using a scale of democratic parenting and selfconcept scale. Data analysis using Pearson Product Moment correlation techniques. The results of this study indicate the value of the correlation coefficient $(r)=0.117$ with a significance value $(p)=0.104$. This value is greater than 0.05 , so it can be interpreted that there is no relationship between democratic parenting to the self-concept of adolescents in SMAN 11 Kendari.

Keywords: Democratic Parenting, Self-Concept, Adolescsent 


\section{Pendahuluan}

Setiap perkembangan anak merupakan suatu proses yang kompleks, tidak dapat terbentuk hanya dari dalam diri anak saja, tetapi juga dengan adanya lingkungan tempat tinggal anak. Lingkungan yang pertama dan paling berpengaruh adalah lingkungan keluarga, dimana orang tua sangat berperan didalamnya. Fenomena saat ini banyak orang tua yang kerap meletakkan harapan - harapan yang terlalu tinggi pada anak mereka, padahal seharusnya harapan itu disesuaikan dengan kemampuan anak itu sendiri. Apabila kemampuan anak tidak sampai apa yang diharapkan orang tua , akibatnya anak akan sering mendapat kritikan, rasa takut, kekecewaan, merasa minder, dan kurang percaya diri, disisi lain ada beberapa orang tua juga yang memahami dan mengerti kemampuan yang dimiliki anaknya dan menerapkan sikap responsive atau tanggap terhadap kebutuhan maupun kemampuan anak mereka. Sikap yang ditunjukan orang tua ini, akan berdampak pada perkembangan anak terlebih lagi dalam masa perkembangan remajanya sehingga peran orang tua sangatlah penting bagi anak dalam menyelesaikan tugas - tugas perkembangannya.

Dalam hal perkembangan psikososial contohnya, masa remaja mengalami perkembangan diantaranya mengalami sebuah proses pencarian identitas baru, dimana mereka mencoba menjelaskan siapa dirinya dan apa perannya (Wong, 2009). Pencarian identitas dan peranannya dalam masyarakat disini adalah merupakan bagian dari pembentukan konsep diri yang dialami remaja (Hurlock, 2004).

Konsep diri merupakan gambaran yang dimiliki seseorang tentang dirinya yang dibentuk melalui pengalaman - pengalaman yang diperoleh dari interaksi dengan lingkungan. Menurut Fitts (dalam Agustiani, 2006) bahwa konsep diri merupakan aspek penting dalam diri seseorang, karena konsep diri seseorang merupakan kerangkan acuan (Frame of
Reference) dalam berinteraksi dengan lingkungan. Konsep diri bukanlah merupakan bawaan sejak lahir, melainkan berkembang seiring dengan adanya pengalaman. Dengan mengetahui konsep diri seseorang, kita akan lebih mudah memahami tingkah laku orang tersebut (Agustiani, 2006), dengan demikian konsep diri merupakan hal yang terpenting dalam setiap individu karena konsep diri yang dimiliki individu akan mempengaruhi perilakunya dalam hubungan sosial dengan individu lainnya. Seperti halnya dikemukakan oleh Tan \& Yates (2007), konsep diri menentukan bahwa individu selektif dalam persepsi rangsangan mereka. Demikian pula, ini menunjukkan bahwa diri bukan hanya stimulus lain dalam sosial tetapi merupakan objek pertimbangan manusia yang paling signifikan. Secara keseluruhan, konsep diri diasumsikan sebagai konstruksi multidimensi yang memiliki satu sisi umum dan banyak sisi tertentu.

Menurut Brook (dalam Rakhmat, 2007) konsep diri merupakan pandangan seseorang tentang dirinya baik fisik, sosial maupun psikologis yang dibangun dan diperoleh dari pengalaman dan interaksi dengan orang lain. Adapun orang lain yang dimaksud dan yang akan menumbuhkan tanda pada konsep diri seseorang anak adalah orang tua, kawan sebaya, dan masyarakat termasuk guru yanga ada di sekolah. Orang tua kita adalah kontak paling awal kita temui dan yang paling berperan karena apa yang dikomunikasikan oleh orang tua pada anak lebih menancap dari pada informasi lain yang diterima anak, dibandingkan dengan masyarakat termasuk guru yang ada disekolah (Muntholi'ah, 2002). Penanaman konsep diri dapat dilakukan dalam pola asuh yang ada dalam keluarga, dan tidak didapatkan disekolah. Konsep diri yang tercermin dari anak sangat berhubungan erat dengan bagaimana pola asuh orang tua saat dirumah pembentukan konsep diri itu sendiri tidak serta merta timbul dan ada begitu saja, akan tetapi 
dibentuk sejak dini, pembentukan konsep diri pada anak tidak terlepas dari peranan keluarga dalam pembentukan konsep diri yang positif.

Keluarga merupakan tempat pertama dan utama untuk pembentukan kepribadian anak terlebih lagi dalam masa remaja. Fungsi keluarga menjadi peranan penting dalam proses sosialisasi anak, setiap orang tua khususnya memiliki pola asuh yang berbeda - beda. Pola asuh orang tua merupakan interaksi yang terjadi antara anak dan orang tua, pola pengasuhan tertentu dalam keluarga akan memberi pengaruh terhadap kepribadian anak (Jahja, 2011).

Menurut Baumrind (2002), pola asuh orang tua pada umunya ada tiga tipe pengasuhan, yaitu pola asuh demokratis, otoriter dan permisif. Pola asuh demokratis adalah pola pengasuhan yang mendorong remaja untuk mandiri tetapi tetap memberikan batasan dan mengendalikan tindakan - tindakan remaja, juga memberikan kesempatan kepada remaja untuk berdialog secara verbal. pola asuh demokratis menurut Papalia (2008), pola asuh otoritatif adalah gaya pengasuhan yang ditunjukkan orang tua dengan bersikap tegas terhadap nilai penting peraturan, norma akan tetapi orang tua bersedia mendengarkan, menjelaskan dan bernegoisasi dengan anaknya. Selanjutnya menurut Sochib (2000) pola asuh demokratis adalah suatu bentuk pola asuh yang memperhatikan dan menghargai kebebasan anak, adanya komunikasi yang dialogis antara anak dan orang tua, dan adanya sikap hangat yang ditunjukkan oleh orang tua kepada anaknya, penerimaan orang tua terhadap anaknya dikarenakan sikap hangat yang ditunjukkan oleh orang tua.

Orang tua yang demokratis bersikap terbuka, fleksibel dan memberikan kesempatan kepada anaknya untuk dapat tumbuh dan berkembang, dengan peraturan yang rasional (Santrock, 2007). Pola asuh otoriter adalah pola pengasuhan yang membatasi dan menuntut anak untuk mengikuti perintah - perintah orang tua . Pola asuh permisif adalah pola pengasuhan orang tua dengan segala aturan dan ketetapan keluarga di tangan anak, orang tua menuruti segala kemauan anak (Baumrind, 2002). Penerapan pola asuh demokratis dapat menumbuhkan konsep diri yang positif bagi remaja.

Hubungan positif antara pola asuh demokratis orang tua dan konsep diri dikuatkan dengan penelitian sebelumnya yaitu penelitian yang dilakukan oleh Rahman, Shahrin, dan Kamaruzaman (2017) mendapatkan hasil bahwa ada hubungan signifikan antara pola pengasuhan demokratis terhadap konsep diri pada remaja. Hal ini juga dikemukakan oleh Santrock (2013) mengatakan bahwa pola asuh demokratis lebih efisien bagi perkembangan remaja dibandingkan pola otoriter dan permisif, penjelasan dari hasil penelitian dan pernyataan tersebut menunjukan bahwa pola asuh demokratis akan lebih efisien digunakan para orang tua untuk membentuk diri anak.

Mengacu pada pernyataan hasil penelitian sebelumnya, peneliti bertujuan untuk meneliti hubungan antara keduanya tetapi sebelum itu perlu dilakukannya pengamatan awal ditempat penelitian yaitu bertempat di SMAN 11 Kendari, sekolah ini merupakan salah satu sekolah memiliki predikat sekolah terbaik dengan akreditas A, didapatkan bahwa sebagian menggambarkan pola asuh yang diterapkan orang tua dalam membentuk anak ialah pola asuh demokratis sejalan dengan ungkapan yang dikemukakan oleh para anak dan didukung dengan pernyataan orang tua mereka.

Peran orang tua sangatlah penting terlebih lagi dengan gaya pola asuh yang mereka berikan kepada anaknya, pola asuh orang tua berarti perilaku orang tua terhadap remaja dan pola asuh sebagai perilaku yang diterapkan orang tua terhadap remaja dapat bersifat relatif konsisten dari waktu ke waktu, sehingga 
ketika remaja yang diasuh oleh pola pengasuhan demokratis dengan tidak memanjakan anaknya namun juga tidak mengekang anaknya akan berdampak baik bagi perkembangan konsep diri anak dalam hal ini remajanya.

Pola asuh demokratis akan memberikan konsep diri yang baik bagi anak dalam masa perkembangannya hal ini telah dijelaskan pada penelitian sebelumnya, yaitu penelitian yang dilakukan oleh Ningrum, Machmuroch, Astriana (2016), dari penelitian tersebut diperoleh kesimpulan terdapat hubungan yang signifikan antara pola asuh demokratis dengan konsep diri remaja. Perbedaan dengan penelitian ini terletak pada teknik pengambilan sampel, tempat penelitian, dan waktu penelitian. Variabel penelitian ini adalah pola asuh demokratis terhadap konsep diri remaja, remaja yang tidak memiliki kebutuhan khusus. Tempat penelitian dilakukan di SMAN 11 Kendari.

Penelitian yang dilakukan oleh Putri (2015), dari penelitian tersebut diperoleh kesimpulan terdapat hubungan yang signifikan antara pola asuh demokratis dengan konsep diri remaja. Perbedaan dengan penelitian ini, terletak pada subjek penelitian yaitu mengambil remaja awal sampai dengan remaja pertengahan. Perbedaan lainnya ada di tempat penelitian, dan waktu penelitian. Tempat penelitian dilakukan di SMAN 11 Kendari.

Berdasarkan paparan fenomena yang disampaikan di atas dan hasil penelitian sebelumnya, maka peneliti merasa perlu melakukan penelitian untuk mengetahui hubungan antara pola asuh demokratis terhadap konsep diri pada remaja di SMAN 11 Kendari.

Penelitian ini bertujuan untuk mengetahui hubungan antara pola asuh demokratis terhadap konsep diri pada remaja di SMAN 11 Kendari.

Manfaat dalam penelitian ini terdiri dari manfaat praktis dan manfaat teoritis, yakni sebagai berikut:

\section{Manfaat Praktis \\ Bagi Siswa}

Siswa dapat memahami bagaimana pola asuh orang tuanya dapat mempengaruhi konsep diri yang ada pada dirinya.

\section{Bagi Peneliti \\ Memberikan gambaran mengenai bagaimana pola asuh demokratis yang diberikan kepada remaja di mana juga dapat mempengaruhi konsep dirinya.}

\section{Manfaat Teoritis}

Penelitian ini diharapkan dapat memperluas wawasan penulis dan pembaca mengenai penerapan pola asuh demokratis yang diterapkan oleh orang tua pada masa remaja yang berhubungan dengan konsep diri remaja.

\section{Metode Penelitian}

Jenis penelitian ini adalah penelitian kuantitatif. Desain penelitian yang digunakan adalah korelasional. Populasi dalam penelitian ini berjumlah 207 siswa SMAN 11 Kendari, penentuan populasi dilakukan dengan cara melakukan screening. Teknik pengambilan sampel secara purposive sampling, Setelah dilakukannya screening pada populasi, peneliti melakukan penentuan sampel dalam penelitian dengan cara membagikan skala dan melihat karakteristik diatas, didapatkanlah sampel dalam penelitian ini berjumlah 117 siswa.

Metode pengumpulan data dalam penelitian ini menggunakan dua skala yaitu skala pola asuh demokratis dan skala konsep diri. Skala pola asuh demokratis dalam penelitian ini merupakan skala yang telah diadaptasi dari penelitian sebelumnya Savitri (2008), memilki validitas berada pada rentang 0,321-0,859 dan reliabilitas 0,951 . Sedangkan skala konsep diri dalam penelitian ini merupakan modifakasi dari skala yang disusun oleh Lintina (2015), memiliki validias berada pada rentan 0,352 0,791 dan reliabilitas 0,814 . 
Pola asuh demokratis ialah bagaimana cara orang tua mendidik dan membimbing anak, dimana orang tua bersikap terbuka terhadap tuntutan dan pendapat yang dikemukakan anak. Pola asuh demokratis diungkap melalui persepsi siswa terhadap orang tua dalam memberikan bimbingan dan menanamkan norma - norma yang ada. Pola asuh demokratis dalam penelitian ini diukur dengan menggunakan skala pola asuh demokratis dari 4 aspek yakni aspek persepsi pandangan orang tua, aspek komunikasi, aspek pemenuhan kebutuhan anak, dan aspek penerapan kontrol, yang dikemukakan oleh Setiawan (1996). Makin tinggi skor total yang diperoleh berarti makin positif siswa mendapatkan pola pengasuhan demokratis. Demikian pula sebaliknya, makin rendah skor total yang diperoleh berarti makin negatif siswa tersebut tidak sedang diasuh dengan pola pengasuhan demokratis.

Konsep diri merupakan pandangan dan penilaian siswa terhadap dirinya sendiri yang meliputi tentang diri, pengharapan bagi diri sendiri, penilaian serta apa yang dipikirkan dan apa yang dirasakan tentang diri sendiri yang berpengaruh terhadap tingkah laku siswa. Konsep diri dalam penelitian ini diukur dengan menggunakan skala konsep diri yakni pertama dimensi internal yang merupakan penilaian individu terhadap dirinya sendiri, didalamnya mencakup diri identitas, diri pelaku, dan diri penerimaan. Kedua dimensi eksternal yang merupakan penilaian diri sendiri melalui hubungannya dengan lingkungannya, didalamnya mencakup diri fisik, diri keluarga, diri pribadi, diri moral etik, dan diri sosial, yang dikemukakan oleh Fitts (1971).

Dalam penelitian ini data dianalisis dengan menggunakan analisis correlation pearson product moment, yakni uji statistik yang digunakan untuk menguji hipotesis bila kedua uji asumsi terpenuhi yaitu data berdistribusi normal dan linear. Perhitungan analisis dilakukan dengan menggunakan bantuan program SPSS Versi 18.0 for Windows.

\section{Hasil Penelitian dan Pembahasan Hasil Penelitian Uji Asumsi}

\section{a. Uji Normalitas}

Tabel 1. Hasil uji normalitas

\begin{tabular}{ccc}
\hline Variabel & $\begin{array}{c}\text { Kolmogorov } \\
\text { Smirnov }\end{array}$ & Signifikansi \\
\hline $\begin{array}{l}\text { Pola Asuh } \\
\text { demokratis }\end{array}$ & 1.146 & 0.144 \\
\hline $\begin{array}{l}\text { Konsep } \\
\text { diri }\end{array}$ & 1.146 & 0.144 \\
\hline
\end{tabular}

Uji Normalitas data dengan menggunakan teknik One-Sample Kolmogrov Smirnov pada SPSS 18.0 menunjukkan nilai signifikansi sebesar 0,144 . Nilai ini lebih besar dari 0,05 , ini menunjukkan bahwa data variabel pola asuh demokratis dan variabel konsep diri terdistribusi secara normal.

\section{b. Uji Linearitas}

Tabel 2. Hasil uji linearitas

\begin{tabular}{lc}
\hline Variabel & $\begin{array}{c}\text { Signifikansi } \\
\text { Deviation from Linearity }\end{array}$ \\
\hline $\begin{array}{l}\text { Pola asuh } \\
\text { demokratis }\end{array}$ & 0,401 \\
\hline $\begin{array}{l}\text { Konsep } \\
\text { diri }\end{array}$ & 0,401 \\
\hline
\end{tabular}

Uji Linearitas data dengan menggunakan Test for Linearity pada program SPSS 18.0 menunjukkan nilai signifikansi deviation from linearity sebesar 0,401. Nilai ini lebih besar dari 0,05, ini menunjukkan bahwa data variabel pola asuh demokratis dan variabel konsep diri mempunyai hubungan yang linear (Sugiyono, 2006). 


\section{Uji Hipotesis}

Uji korelasi Pearson Product Moment

Tabel 3. Hasil uji korelasi Pearson Product Moment

\begin{tabular}{lcc}
\hline Variabel & $\begin{array}{c}\text { Person } \\
\text { Correlation }\end{array}$ & Signifikansi \\
\hline $\begin{array}{l}\text { Pola Asuh } \\
\text { Demokratis }\end{array}$ & 0,117 & 0.104 \\
\hline Konsep diri & 0,117 & 0.104 \\
\hline
\end{tabular}

Hasil data menunjukkan nilai signifikansi 0,104. Nilai ini lebih besar dari 0,05 , sehingga dapat dikatakan bahwa tidak terdapat hubungan secara signifikan antara pola asuh demokratis terhadap konsep diri remaja, dimana arah angka koefisien korelasi hasilnya positif yakni 0,117 , ini berarti menunjukan adanya arah hubungan yang satu arah yakni semakin tinggi pola asuh demokratis yang diberikan maka akan semakin tinggi konsep diri pada siswa.

\section{Pembahasan}

Berdasarkan uji hipotesis yang telah dilakukan, peneliti melihat beberapa faktor pendukung yang dapat menyebabkan variabel pola asuh demokratis dengan konsep diri tidak memiliki hubungan secara signifikan, antara lain ditinjau dari subjek penelitian dalam penelitian ini peneliti mengambil usia remaja, dimana pada umumnya diketahui bahwa pada masa usia ini, remaja lebih banyak menghabiskan waktunya diluar rumah, bermain dengan teman sebayanya sehingga hubungan mereka dengan orang tuanya tidak begitu tercipta.

Pada masa ini, kurangnya perhatian orang tua kepada anak karena kurang intensnya anak berada didalam rumah, sehingga ikatan remaja dengan orang tuanya menjadi renggang karena adanya perubahan perhatian, kurangnya komunikasi diantara keduanya sehingga dapat dikatakan bahwa pola asuh demokratis tidak berjalan baik dalam proses pembentukan konsep diri remaja, dalam hal ini komunikasi harusnya tercipta lebih intens guna untuk dapat dijadikan sebagai suatu alternative penyampaian pesan ke remaja serta sebagai jembatan penghubung interpersonal dalam upaya pendekatan serta menilai anak. Pernyataan ini sejalan dengan yang dikemukakan oleh Erikson (2014) bahwa pada remaja pengaruh teman sebaya cukup kuat karena pada masa ini remaja lebih banyak menghabiskan waktu bersama teman - teman daripada keluarga.

Saraswatia (2015) menyatakan bahwa salah satu faktor yang mempengaruhi terbentuknya konsep diri bukan hanya dari orangtua melainkan teman sebaya, sejalan dengan penelitian yang dilakukan oleh mengatakan bahwa faktor yang mempengaruhi konsep diri remaja yaitu adanya pengaruh teman sebaya. Hasil penelitian tersebut sejalan dengan pernyataan Jalaludin (2005), bahwa faktor yang berhubungan dengan pembentukan konsep diri yaitu seperti penilaian, sikap dan respon orang - orang disekitar individu serta pengaruh kelompok teman sebaya yang mengarahkan perilaku individu harus sesuai dengan aturan dalam kelompoknya.

Selanjutnya, faktor lain dapat dilihat dari kesibukan orang tua dalam bekerja, dari beberapa responden dalam penelitian ini tidak sedikit orang tua mereka, bekerja diluar rumah sehingga kurangnya waktu bersama orang tua nya dapat menjadi faktor selanjutnya mengapa pola asuh orang tua yang demokratis tidak berhubungan dengan konsep diri remaja karena kurangnya waktu orang tua dirumah. Pernyataan ini sejalan dengan yang dikemukakan oleh Gunarsa (2006), kurang intensnya orang tua berada dalam rumah dapat menjadi pemicu kurangnya perhatian ke anak dan akan berdampak pada proses pembentukan kepribadian pada usia remajanya.

Hasil penelitian ini sejalan dengan penelitian yang dilakukan oleh Mutrofin (2014), menyebutkan bahwa tidak ada hubungan antara pola asuh demokratis dengan konsep diri remaja tuna daksa di panti rehabilitasi. Berdasarkan teori dan 
penelitian-penelitian terdahulu yang telah dipaparkan, bahwa ada beberapa faktor yang menyebabkan variabel pola asuh demokratis dengan konsep diri, tidak mempunyai hubungan secara signifikan, yakni dilihat dari subjek penelitian dan faktor kondisi sosial ekonomi orang tua.

Selanjutnya adapun keterbatasan dalam penelitian ini ialah, dalam pengambilan data tidak semua responden dapat dijumpai, karena ada kelas yang tidak mengikuti diwaktu peneliti mengambil data. Serta keterbatasan waktu yang diberikan oleh pihak sekolah, sehingga peneliti tidak dapat sepenuhnya memberikan penjelasan terkait dengan alat ukur, hal ini berdampak pada responden ada yang tidak memahami cara mengisi skala terkait dengan kedua variabel dan keterbatasan penelitian lain yakni peneliti tidak bisa melihat sumbangsih antara kedua variabel, sehingga diharapkan peneliti selanjutnya perlu menambahkan metode penelitian, guna untuk melihat seberapa besar sumbangsih antara kedua variabel.

\section{Kesimpulan dan Saran Kesimpulan}

Berdasarkan penelitian yang telah dilakukan, dapat disimpulkan bahwa hipotesis dalam penelitian ini ditolak, dengan nilai signifikansi sebesar 0,104. Nilai tersebut lebih besar dari 0,05 artinya tidak terdapat hubungan yang signifikan antara pola asuh demokratis terhadap konsep diri remaja dan nilai koefisien korelasi bernilai positif sebesar 0,117 artinya semakin tinggi pola asuh demorkatis maka akan dibarengi dengan semakin tingginya konsep diri pada remaja, sebaliknya semakin rendah pola asuh demorkatis maka akan dibarengi dengan semakin rendah pula konsep diri pada remaja pada siswa SMAN 11 Kendari.

\section{Saran}

1. Bagi siswa SMAN 11 Kendari

Diharapkan bagi setiap siswa dapat menanamkan konsep diri yang baik dalam dirinya, dapat meningkatkan rasa percaya diri ketika berada dilingkungan luar, serta dapat mengembangkan kemampuan yang dimilikinya hal tersebut merupakan bagian dari proses terbentuknya konsep diri.

2. Bagi orang tua

Orang tua hendaknya lebih memperhatikan dan mengawasi anak khususnya dalam usia remajanya serta dapat membagi waktu bersama anak sekalipun orang tua sibuk bekerja, walaupun hanya sekedar menanyakan keadaan ataupun kondisi anak.dengan cara alternative menggunakan alat komunikasi.

3. Bagi Sekolah

Sekolah diharapkan dapat menciptakan suasana yang mendukung untuk tumbuhnya konsep diri yang baik. Membantu siswa mengenali dirinya dan mengembangkan potensi diri, memberi penghargaan terhadap prestasi yang diraih siswa dalam bidang akademik maupun non akademik, dan dapat membantu terwujudnya konsep diri.

4. Bagi penelitian selanjutnnya

a. Diharapkan bagi peneliti selanjutnya untuk mencari faktor - faktor lain yang mempengaruhi pola asuh demokratis dengan konsep diri. Hal ini dikarenakan dalam penelitian ini, pola asuh demokratis tidak begitu berperan penting dalam pembentukan konsep diri pada anak pada usia remajanya.

b. Peneliti selanjutnya disarankan untuk memperhatikan jumlah sampel antara laki-laki dan perempuan, karena dengan perbandingan sampel yang seimbang dari segi jenis kelamin diharapkan hasil penelitian selanjutnya yang diperoleh dapat lebih akurat

\section{Daftar Pustaka}

Agustiani, H. (2006). Psikologi perkembangan. Bandung: PT. Refika Aditama. 
Baumrind, D. (1971). Current patterns of parental authority. Retrieved from http;//www.thebiganswer.info/books/cu rrent-patterns-of-parental-authority.php

Erikson, E. (2014). Chilhood and society. New York: W.W Norton \& Company

Fitts, W. H. (1971). The self concept and self actualization. California: Western Psychological Service.

Gunarsa, S. (2006). Psikologi perkembangan anak dan dewasa. Jakarta: Gunung Mulia

Hurlock, E. B. (2004). Psikologi perkembangan. Jakarta: PT. Gelora Aksara Pratama.

Hurlock, E. B. (2007). Psikologi perkembangan: suatu pendekatan sepanjang rentan kehidupan (edisi kelima). Jakarta: Erlangga.

Jahja, Y. (2011). Psikologi perkembangan. Jakarta: Kencana.

Jalaludin, R. (2005). Metode penelitian komunikasi. Bandung: PT. Remaja Rosda Karya

Muntholi'ah. (2002). Konsep diri penunjang prestasi PAI. Semarang: Gunung Jati.

Mutrofin, I. (2014). Hubungan antara kecenderungan pola asuh demokratis dengan konsep diri remaja tuna daksa di Panti Rehabilitasi.( Skripsi). UIN Sunan Ampel, Surabaya.

Ningrum, M.I., Machmuroch, \& Astriana, S. (2016). Hubungan antara pola asuh demokratis dan konsep diri dengan perilaku prososial siswa di kelas Inklusi SMPN 12 Surakarta. (Skripsi
Tidak Diterbitkan). Surakarta: Universitas Sebelas Maret.

Papalia, D. E. (2008). Human development (Psikologi perkembangan). Jakarta: Kencana Prenada Media Group.

Putri, A. (2015). Hubungan antara kecenderungan pola asuh demokratis ayah dengan konsep diri pada remaja. (Skripsi). Sekolah sarjana Universitas Muhammadiyah, Surakarta

Rakhmat, J. (2007). Psikologi komunikasi. Bandung: PT. Raja Rosdakarya.

Santrock, J.W. (2007). Perkembangan anak (edisi kesebelas.). Jakarta: Kencana.

Santrock, J.W. (2013). Life span defelopment (14th ed). New York: Mcgraw Hill Compaines, Inc.

Saraswatia, K. G. (2015). Faktor - faktor yang mempengaruhi konsep diri remaja di SMPN 13 Yogyakarta. Journal Ners and Midwifery Indonesia, 3(1), 33-36.

Sochib, M. (2000). Pola asuh orang tua dalam membantu anak mengembangkan disiplin diri. Jakarta: Rineka cipta.

Tan, J., \& Yates, S.M. (2007). A rasch analysis of the academic self-concept questionnaire. International Education Journal, 8(2). 470-484. 